\title{
Making Monsters: The Polygraph, the Plethysmograph and other Practices for the Performance of Abnormal Sexuality
}

Authors:

Andrew S. Balmer

Department of Sociology

University of Manchester

Manchester M13 9PL

andrew.balmer@manchester.ac.uk

01612752488

Final Submission Date: 17.08.2012

Abstract words: 142

Article words: 9,841

Total words: 10, 057
Ralph Sandland

School of Law

University of Nottingham

Nottingham NG7 2RD

$\underline{\text { Ralph.Sandland@ @ottingham.ac.uk }}$

01159515716

Keywords: sex offenders; paedophile; polygraph; plethysmograph; abnormal; sexuality; risk management

\section{Abstract}

This article addresses the use of the polygraph, penile plethysmograph and other practices for the management of sexual offenders as part of the 'Containment Approach', a strategy that is increasingly common in the USA and is, in part, being trialled in the UK. The polygraph has a tangled history with abnormal sexuality, as we describe in the context of homosexuality in the 1960s. We examine how these strategies target sex offenders as malleable in regard to sexual performances but also, through notions of risk management, paradoxically constitute offenders as fundamentally incurable and thus permanently risky. Using Foucault's notion of the 'abnormal' we investigate the implications of this risk management/performance paradox. We conclude that it reveals a certain anxiety about the relationship between abnormal and normal sexual behaviour in contemporary sex offender management discourse, which can help explain the emergence of these practices. 


\section{Introduction}

Although its scientific status has remained controversial since its design in the early 1900s the polygraph machine has become synonymous with 'lie detection', so much so that it is often simply referred to as the lie detector. Although a great deal has been written about the polygraph as regards its admissibility in US criminal trials, very little has been written about its use in the context of probation programmes and even less with a specific emphasis on sex offender management. This is curious, since in the US the device has become ever more significant in this context, and - as we intend to demonstrate - plays an important role in producing knowledge about the sex offender and in the construction of his treatability and disorder. That being said, important work has been carried out on the role of the sex offender as part of the 'new penology', some of which has focussed on the ever more potent forms of punishment to which he is subject. However, this work hasn't engaged with the polygraph machine and only touches upon the plethysmograph and other treatment practices. In this paper we seek to provide a novel account of the emergence of the polygraph in the management and treatment of sex offenders in the USA and to provide some detail of its more recent spread to the UK. We do so by weaving together a number of theories, including several strands of Foucault's work and contemporary analyses of punishment and criminal management to examine the scientific and policy literature on sex offender management. Thus, we describe the way in which the polygraph has become entangled with sex, deviance and identity.

Our analysis begins with a description of its use as a mode of outing homosexuals in the US government, we then move into the subject matter proper and argue that, in the United States in particular, the polygraph machine is becoming an indispensable means of managing sex offenders. The polygraph facilitates the creation of a particular kind of deviant individual, in order that they become amenable to actuarial mechanisms of risk prediction and to processes of self-control. Importantly, the use of the polygraph, plethysmograph and other practices in the treatment programmes of sexual offenders is fundamentally tied to the performance of an altogether alien, indeed 'monstrous' identity. To begin, however, we briefly explain the mode of operation of the machine more generally and outline some of its historical development.

\section{The Polygraph Machine}

What Alder ${ }^{1}$ calls 'the American obsession' with lie detectors properly began at Harvard in 1915 with Hugo Munsterberg's research into physiological correlates of deception and his student William Marston who refined this into the systolic blood pressure deception test. Marston and others involved in the early life of the polygraph sought to quantify, compare and aggregate physiological records to make visible normal and deviant psychological states. ${ }^{2}$ They treated the body as an instrument upon which the emotions played, a body that responded to these emotions and could

\footnotetext{
${ }^{1} \mathrm{~K}$. Alder, The Lie Detectors: The History of an American Obsession, (2007).

${ }^{2}$ K. Alder 'A Social History of Untruth: Lie Detection and Trust in Twentieth-Century America' (2002) 80 Representations 1.
} 
thus be examined and interpreted for their content. ${ }^{3}$ In this tradition, the central logic of the polygraph was that lying caused emotional changes, namely fear and guilt, and that these produced physiological changes that could be measured in order to discern a subject's veracity.

The polygraph machine as we know it today developed through the assemblage of other instruments, and now consists of a number of devices designed to record physiological phenomena, such as the blood pressure cuff, pneumograph and galvanometer. These are used to record bodily responses during a verbal interview, in which a series of questions are asked, to which simple 'yes' or 'no' answers are provided. The record is then scored to reflect the changes in arousal that accompany verbal responses to different types of questions. This organisation of the interview and the logic on which the data is interpreted is known as the 'Control Question Test' or CQT. The CQT is the most widely used methodology, though an alternative procedure, the Guilty Knowledge Test (GKT, or 'Concealed Information Test' CIT), is also available.

Gershon Ben-Shakhar, one of the most prominent experts on lie detection techniques, summarises the CQT process thus:

\begin{abstract}
The questions are of three general types: (a) Relevant questions..."Did you do it?"; (b) Control questions - focusing on general, non-specific misconducts... (e.g., "Have you ever taken something that did not belong to you?"); (c) Irrelevant questions - focusing on completely neutral issues (e.g., are you sitting on a chair?) ... Typically, the whole question series is repeated three or four times. ...[then there is] a comparison of the responses evoked by the relevant and the control questions. Deceptive individuals are expected to show more pronounced responses to the relevant questions, whereas truthful individuals are expected to show the opposite pattern of responsivity." ${ }^{4}$
\end{abstract}

This method of lie detection has been heavily criticised on the one hand, and stalwartly defended on the other and it seems even today, after nearly a hundred years of use, the status of the polygraph as a scientific technique remains unsettled. The device inhabits a strange position somewhere between valid, since there are scientific proponents of the device and it is regularly used in a number of contexts in the USA, and invalid, since it has its scientific opponents and the US courts have been reluctant to whole-heartedly accept $i^{5}$ as expert evidence. This current ambiguity in the application of the polygraph is reflected in its scientific history. Alder argues ${ }^{6}$ that there was a bifurcation of the polygraph's development along lines separately pursued by two of its early advocates, John Larson and Leonard Keeler. Alder refers to their different strategies as the knowledge-line (Larson) and the power-line (Keeler). He suggests the technique has not been accepted by the US trial courts because of the pollution of the scientific, knowledge-based discourse by the power-based rhetoric that sought out advertisements and populism. He argues that the difficulty experienced in making

\footnotetext{
${ }^{3}$ S. Weber, The Hidden Truth: A Sociological History of Lie Detection, (2008). PhD Thesis.

${ }^{4} \mathrm{G}$. Ben-Shakhar 'A Critical Review of the Control Questions Test (Cqt)' in Handbook of Polygraph Testing, ed. M. Kleiner (2002) 103-126

${ }^{5}$ Beginning, for example, with Frye v. United States, and more recently confirmed in USA v. Scheffer. However, the polygraph is admissible in a number of states when all parties stipulate prior to the examination that the results can be admitted as evidence irrespective of its outcome. See, for an overview of state cases: A. Shniderman 'You Can't Handle the Truth: Lies, Damn Lies, and the Exclusion of Polygraph Evidence' (2011) 22 Albany Law Journal of Science and Technology 433.

${ }^{6}$ Alder, op. cit. n. 1
} 
polygraph evidence admissible in US trials is due, in part, to the inability of these two lines to be reconciled into a profession capable of self-regulation. Whilst acknowledging Alder's important contribution to the study of lie detection, Weber $^{7}$ does some excellent work in replacing this overly simplified and hierarchical way of thinking about science as valid or invalid, professional or unprofessional. She provides a more sociologically symmetrical exploration of the debate between Larson and Keeler over what would constitute sufficient training in polygraphy. What both authors usefully contribute is an account of how the polygraph's early decades failed to establish it as a sufficiently reliable and valid technique for use in the US courts. But that was quite some time ago.

A more recent report by the National Research Council (NRC) in the US (part of the National Academy of Sciences, the NAS), found the polygraph still lacking. In its opening pages the report claimed that "Almost a century of research in scientific psychology and physiology provides little basis for the expectation that a polygraph test could have extremely high accuracy." ${ }^{8}$ The NRC report, having reviewed the research, found that virtually all evidence on polygraphy came from studies of specific-event investigations and that the majority of relevant studies were below the quality typically demanded by NSF or NIH-funded research. Despite this lifetime of contestation the machine still finds use in a range of US government departments and by the police during criminal investigations. How it is that the device still finds credence in specific sites of application, we believe, has to be interpreted on a case-by-case basis, since in the context of sexuality, for instance, the discursive production of validity is importantly framed by its particular effects on the sex offender. We describe in later sections how the machine has found itself used to manage desire despite sustained critique of its potentially flawed nature. In order to understand this contemporary use, however, it will prove instructive to briefly examine some of its historical entangling with sexuality in the context of 1950s American politics.

\section{Lie Detection and Homosexuality}

Despite this long-lived controversy surrounding the technology, by the middle of the $20^{\text {th }}$ century almost two million polygraph tests were being administered every year in the United States in police work, for screening employees, for national security checks and in publicity stunts. ${ }^{9}$ These decades saw massive expansion in use of the machine, particularly during the McCarthyite period. The Cold War and the climate of suspicion, coupled with concerns of serious intelligence infiltration by foreign agents, propelled the polygraph front and centre as a tool, perhaps a weapon, to defend the security of the United States against the outside enemy. But that enemy wasn't only the political evil of communism; there was also a sexual monster to be confronted.

In the forties and early fifties the U.S. State Department had come to be seen as a "haven for sexual deviants." ${ }^{10}$ In what would become known as the 'Lavender Scare', the counterpart of McCarthyism's 'Red Scare', Senator McCarthy himself claimed that sexual perverts were "Perhaps as dangerous as

\footnotetext{
${ }^{7}$ Weber, op. cit. n. 3

${ }^{8}$ N.R.C., The Polygraph and Lie Detection, (2003).

${ }^{9}$ Alder, op. cit. n. 2

${ }^{10}$ D.K. Johnson, The Lavender Scare: The Cold War Persecution of Gays and Lesbians in the Federal Government, (2004).
} 
the actual Communists." ${ }^{\prime 1}$ The polygraph machine, proving not to be terribly useful in the questioning of potential communists, ${ }^{12}$ was instead adopted to play a major role in the interrogative procedures of the ominously titled 'Miscellaneous M Group', an investigative unit set-up to handle any type of moral deviation at State, though the focus was overwhelmingly on homosexuality. In 1953 they achieved a 'success rate' of around one forced resignation every two-to-three days ${ }^{13}$.

In a memoir on his work as a CIA polygraph examiner during this period, John F. Sullivan ${ }^{14}$ suggests that " $\mathrm{ClA}$ examiners over the years probably obtained more disqualifying information regarding homosexual activity than any other issue... With the exception of criminal activity... most employees who lost their clearances lost them as a result of admissions of homosexual activity." In reviewing Sullivan's book another examiner laments that "The hunt for homosexuals was indeed vigorous. I had a number of male and female friends who suddenly disappeared from the Agency. I would see them one day and the next day they were gone."15

The machine thus found a temporary home on the fringes of American identity: it was used to police the boundary between capitalist and communist, and between hetero- and homosexual. Both of these binaries served to protect the norm of American life and both produced categories of people that were abnormal. It is our contention that the polygraph has retained this role in the context of moral panics over sex offenders.

\section{Paedophiles and the New Penology}

The use of the polygraph machine for post-probation management of sex offenders falls within a framework that is frequently referred to as the 'containment approach'. Such use of the machine can be traced to the 1960s as concerns about homosexuality began to diminish and McCarthyism declined. Indeed, by the nineties homosexuality was no longer officially seen as inherently connected to disloyalty and untrustworthiness. Thus, the epicentre of sexual deviance in State policy and policing was no longer homosexual activity per se, in the way that it had been in the US and indeed in the UK before the passage of the Sexual Offences Act 1967. ${ }^{16}$ This shifting of the apparatus around homosexuality is reflected in its finally being dropped from the major international diagnostic manuals of mental disorder: in 1974 from the DSM and 1993 from the WHO's ICD ${ }^{17}$. Following this, the many interventions and technologies designed or used to 'cure' those 'afflicted' were abandoned or found new targets. It was during this period of transition in norms and technopolitics that the polygraph properly began to spread across the U.S. for use in probation settings.

\footnotetext{
${ }^{11}$ Alder, op. cit. n. 1

12 J.F. Sullivan, Gatekeeper: Memoirs of a Cia Polygraph Examiner, (2007).

${ }^{13}$ Johnson, op. cit. n. 10

${ }^{14}$ Sullivan, op. cit. n.12

${ }^{15}$ R.D. Chapman 'To Tell the Truth' (2008) 21 International Journal of Intelligence and Counterintelligence 401.

${ }^{16}$ D. Mcghee, Homosexuality, Law, and Resistance, (2001).

${ }^{17}$ Homosexuality was removed in 1974 from the American Psychiatric Association's Diagnostic and Statistical Manual of Mental Disorders (DSM, currently in its $4^{\text {th }}$ edition and so known as DSM-IV) but it took until 1993 for the World Health Organisation's International Statistical Classification of Diseases and Related Health Problems (ICD, currently in its $10^{\text {th }}$ edition and so known as ICD-10) to remove the category.
} 
In 1966 Judge Clarence Partee of Illinois began use of the polygraph to elicit confessions of other crimes when sentencing criminals in his court, and Judge John Tuttle of Washington began requiring periodic examinations of probationers in $1969 .{ }^{18}$ The use of the device began to spread and it was in the late 1980s that Oregon became the first state systematically to implement the polygraph as a tool in the management and treatment of the modern sexual monster. ${ }^{19}$ In 1995 , the Tennessee legislature passed a law that made polygraph testing mandatory for sex offenders on probation. ${ }^{20}$ Colorado followed suit in $1996 .{ }^{21}$ South Carolina in $2006^{22}$ and Hawai'i, basing its program on these forerunning states, now also requires polygraphy. ${ }^{23}$ Florida Statutes oblige judges considering probation to order sex offenders to submit to the test. ${ }^{24}$ Illinois passed the 'Sexually Dangerous Persons Act' in $1999^{25}$, which includes polygraph conditions for inmates; similarly Kansas is using the technique with sex offenders in its prison population. ${ }^{26}$ California, ${ }^{27}$ Colorado, ${ }^{28}$ Florida, ${ }^{29}$ Indiana, ${ }^{30}$ New Mexico, ${ }^{31}$ and Texas $^{32}$ have all developed guidelines for polygraph examination with sex offenders. This governance strategy spread across the US and meant that by 1996 around $30 \%$ of individual probation programmes reported use of the technique in post-conviction sex offender treatment, escalating to $60 \%$ by 2000 and then rising further to $70 \%$ in 2002 and $79 \%$ in $2009 .{ }^{33}$

In Britain it was the infamous case of the spy Geoffrey Prime that first brought the issue of the polygraph to the consideration of government, which - until then - had kept the device at a legislative arm's length across the Atlantic. ${ }^{34}$ Originally intending to undertake trials of the polygraph

18 J.M. Shaw 'Casenote: Sex, Lies and Polygraph Machines: The Portrait of Mr. Cassamassima' (2002-2003) 57 University of Miami Law Review 429.

${ }^{19}$ C.S.O.M., The Importance of Assessment in Sex Offender Management: An Overview of Key Principles and Practices, (2007). <http://www.csom.org/CSOMResources/documents.html> Last accessed 18.08.2012

20 Tennessee House Bill Number HB0308, 1995

${ }^{21}$ CO.S.O.M.B 'Standards and Guidelines for the Assessment, Evaluation, Treatment and Behavioural Monitoring of Adult Sex Offenders' (2008)

<http://dcj.state.co.us/odvsom/Sex Offender/SO Pdfs/2008\%20Adult\%20Standards\%20FINAL.pdf > last accessed 16.01.12.

22 S.C.D.P.P.P.S., Sex Offender Management Supervision Strategies, (2006).

<http://www.dppps.sc.gov/Jessie's\%20Law2.pdf> Last accessed 18.08.2012.

23 J. Tanabe 'Right against Self-Incrimination V. Public Safety: Does Hawai'I's Sex Offender Treatment Program Violate the Fifth Amendment?' (2000-2001) 23 University of Hawai'i Law Rev. 824.

24 J.M. Shaw 'Casenote: Sex, Lies and Polygraph Machines: The Portrait of Mr. Cassamassima' (2002-2003) 57 University of Miami Law Review 429.

25 W.W. Blair 'The Illinois Sexually Dangerous Persons Act: The Civilly Committed and Their Fifth Amendment Rights, or Lack Thereof' (2004-2005) 29 Southern Illinois University Law Journal

${ }^{26}$ K.C. Eastman 'Sexual Abuse Treatment in Kansas's Prisons: Compelling Inmates to Admit Guilt' (1998-1999)

38 Washburn Law Journal 949.

${ }^{27}$ http://www.ccoso.org/papers/polygraphdraft.pdf last accessed 16.01 .12

28 http://dcj.state.co.us/odvsom/Sex Offender/SO Pdfs/2008\%20Adult\%20Standards\%20FINAL.pdf last accessed 16.01 .12

${ }^{29}$ http://www.floridapolygraph.org/node/3 last accessed 16.01 .12

30 http://www.indianapolygraphassociation.com/testing.asp last accessed 16.01 .12

31 http://www.forensic-centre.com/files/PCSOTOverview.pdf last accessed 16.01.12

32 http://antipolygraph.org/documents/csotpoly.pdf last accessed 16.01 .12

33 R.J. Mcgrath, et al., Current Practices and Emerging Trends in Sexual Abuser Management, (2010).

${ }^{34}$ R. Thomas 'Protective Security Procedures in the Public Service: Some Recent Developments' (1983) 61 Public Administration 429. 
for use in screening employees, plans were abandoned following a critical study by the British Psychological Society. ${ }^{35}$ That might have been the end of the story for the device in the UK, had it not been for the 2005 Labour Party Manifesto, which contained a commitment to trial the use of mandatory polygraph examinations on sex offenders in the community. Under the elected government's changes to the Offender Management Act (OMA 2007) sections 28 and 29 of the OMA 2007 now allow for the attachment of a 'polygraph condition' to the terms of the release from prison on licence of persons convicted of specified sexual offences. These were brought into force early in 2009 in order for the polygraph to be piloted in the East and West Midlands and those trials ended in March 2012.

The introduction of the polygraph isn't the only change the Labour administration pursued to monitor and manage sex offenders. Indeed, this particular criminal category became a key target for the policy of being 'tough on crime' that dominated the rhetorical debate between Labour and the Conservatives during the nineties ${ }^{36}$. A variety of other measures are now to be found in the Criminal Justice Act 2003 (CJA 2003) and Sexual Offences Act 2003 (SOA 2003). The CJA 2003, for instance, requires that a sentence of imprisonment for life on the grounds of public protection be passed on a person convicted of a specified sexual offence ${ }^{37}$ where the court is satisfied that there is otherwise a significant risk of serious harm being caused to a member of the public. ${ }^{38}$ It also provides for extended periods (up to eight years) of supervision following release on licence from prison for persons convicted of specified sexual offences. ${ }^{39}$ The SOA 2003 provides for the registration of sex offenders with their local police ${ }^{40}$ and gives police powers to apply for a 'risk of sexual harm order' (RSHO) in respect of a person in the local area where it appears to the officer that that person has committed two specified sexual offences involving children ${ }^{41}$ and there is reasonable cause to believe that it is necessary that the order be made. ${ }^{42}$

This toughening of the punitive and surveillance forces that act upon the sex offender is characteristic of a more general shift that occurred during this period in the United Kingdom and the United States. A number of scholars have now contributed to the understanding of a 'new penology'43 and of 'hyper innovation' ${ }^{\prime 4}$ that have come to dominate Western governance. These discourses cyclically create ever more regulation ${ }^{45}$ and justify ever more severe punishment, ${ }^{46}$ with rhetorical condemnation of offenders and deviant families, seen as being pathologically criminal,

\footnotetext{
${ }^{35}$ D.T. Wilcox 'Application of the Clinical Polygraph Examination to the Assessment, Treatment and Monitoring of Sex Offenders' (2000) 5 Journal of sexual aggression 134.

${ }^{36}$ T. Newburn '“Tough on Crime": Penal Policy in England and Wales' (2007) 36 Crime and Justice 425.

${ }^{37}$ These are listed at schedule 15, part 2 to the 2003 Act.

38 S. 225 CJA 2003.

${ }^{39}$ S. 227 CJA 2003.

40 See Part 2, SOA 2003.

${ }^{41}$ See s. 123(3) SOA 2003.

42 S. 123 SOA 2003.

${ }^{43}$ M.M. Feeley and J. Simon 'The New Penology: Notes on the Emerging Strategy of Corrections and Its Implications*' (1992) 30 Criminology 449.

${ }^{44}$ A. Crawford 'Networked Governance and the Post-Regulatory State?' (2006) 10 Theoretical Criminology 449.

${ }^{45}$ A. Crawford 'Governing through Anti-Social Behaviour' (2009) 49 British Journal of Criminology 810.

${ }^{46}$ I. Brownlee 'New Labour-New Penology? Punitive Rhetoric and the Limits of Managerialism in Criminal Justice Policy' (1998) 25 Journal of Law and Society 313.
} 
becoming the norm in a system organised around the actuarial management of risky groups and categories. ${ }^{47}$ The increasing concentration on risk has created a particularly strong call for the management of paedophiles who are now subject both in the US and the UK to more stringent controls than seemingly any other group, for example in the use of victim-centred practices such as Megan's Law ${ }^{48}$. Public demands for retribution and the government's populist response are characteristic of a 'moral panic' and have led to a construction of the sex offender in this new penological landscape as profoundly 'other' and, most apposite as regards our current concerns, as 'monstrous'49. We will later return to our specific interest in the polygraph and plethysmograph by bringing this penological trajectory together with an analysis of the practices of the 'containment approach' in order to understand the offender's construction as fundamentally deceptive and risky. But first, we turn now to an explication of this othering of the paedophile as a monstrous outside to normal sexuality by drawing, in particular, on Foucault's arguments regarding the 'abnormal'.

\section{The Polygraph, the Plethysmograph and the Abnormal}

When used in the treatment and management of sex offenders the polygraph has a number of specific functions. The first is part of the well-established surveillance practices in operation around post-conviction sexual offenders, in which the machine is used to test whether subjects are complying with the terms of their probation. This is known as the monitoring examination, which might ask questions like "Did you visit the victim's house last Monday?" 50 It is this more surveillanceoriented form that has been central to the recent trials of the device in the UK.

The second use of the polygraph is ostensibly as part of the therapeutic intervention, in which it is used to help obtain detailed information about the offender's desires, masturbatory practices, fantasies, previous crimes, patterns of behaviour, modes of grooming and victim selection, and numerous other data about the offender's criminal and deviant lifestyle. This is known as the sexual history disclosure examination. An example of a broad question that might be asked during this kind of exam could be: "Do you masturbate to fantasies of non-consensual sex?"

Obtaining a sexual history is a standard procedure in the treatment of sex offenders. According to the Arizona guidelines the kinds of things that are investigated during a sexual history exam include:

Age of onset of expected normal behaviors ... degree of use of pornography, phone Sex, cable, video, or internet for sexual purposes, current and past range of sexual behavior... thoughts [and fantasies] preceding and following crimes; ... masturbation, use of tools, utensils, food, clothing, current sexual

\footnotetext{
${ }^{47}$ P. O'malley, Risk, Uncertainty and Government, (2004).

${ }^{48}$ A.M. Mcalinden 'The Use of 'Shame'with Sexual Offenders' (2005) 45 British Journal of Criminology 373, A.M. Mcalinden 'Managing Risk from Regulation to the Reintegration of Sexual Offenders' (2006) 6 Criminology and Criminal Justice 197, A.M. Mcalinden 'Vetting Sexual Offenders: State over-Extension, the Punishment Deficit and the Failure to Manage Risk' (2010) 19 Social \& Legal Studies 25.

49 D. Garland 'On the Concept of Moral Panic' (2008) 4 Crime, Media, Culture 9, J. Simon 'Managing the Monstrous: Sex Offenders and the New Penology' (1998) 4 Psychology, Public Policy, and Law; Psychology, Public Policy, and Law 452.

50 McGrath, op. cit. n. 33
} 
practices... motivation to change... attitudes [including sexual] toward women, men, children...level of denial, level of deception. ${ }^{51}$

This examination is thus one mode through which the offender's desires are made visible. If, as he is often understood to be, he is in denial of his condition or refuses to acknowledge his crimes, if he is deceptive, then the polygraph becomes a useful tool in producing the knowledge of his abnormal sexual history.

In addition, use of the penile plethysmograph may complement the polygraph's interrogation of his desire. It is a device designed to measure changes in sexual arousal by one of two methods: a volumetric air chamber can be placed over the subject's penis, this measures the swelling that occurs as a result of increased blood volume; or a circumferential transducer, in essence a rubber ring, is placed around the penis to measure changes in circumference. Whilst this apparatus is in place, sex offenders may be exposed to visual images or auditory descriptions of different types of sexual activity with various types of partner. Images of real children have been used and may still be in use but it has become taboo, as such the use of computer-fabricated images of children and adults appears to be more acceptable now. ${ }^{52}$ Indices comparing responses to paedophilic images can be compared to responses during exposure to adult-appropriate sexual imagery, or comparisons can be made between responses during visualisation or descriptions of consenting sex versus nonconsenting sex. These indices are believed to show mean differences between offenders and nonoffenders. ${ }^{53}$ McGrath et al. ${ }^{54}$ report that the percentage of United States programmes reporting use of the penile plethysmograph has remained relatively constant over the last two decades, and is currently used in $28 \%$ of adult community programs and $37 \%$ of adult residential programmes. To our knowledge the device isn't used in UK treatment programmes and nor has it been proposed.

The purpose of producing all of this information about what the offender likes to masturbate to or how much his penis enlarges in response to audio descriptions of non-consensual sex is to 'know the offender', and in this respect the sexual history examination fits a much longer trajectory of knowledge production about deviant desires. To understand this use of the polygraph and plethysmograph in relation to abnormality we draw on Foucault ${ }^{55}$, who has argued that the 'abnormal' is a distinctly modern category. In Foucault's description the abnormal was created in the period during which psychiatry became a potent force in the medico-juridical space and as it connected up with the management of the family. His genealogical analysis describes how the modern abnormal was constituted on the basis of three historical figures: the human monster; the individual to be corrected; and the onanist, or masturbator. The first of these, the human monster, was a medico-juridical concept in that the monster violates all laws, including the laws of nature. ${ }^{56}$

\footnotetext{
${ }^{51}$ Arizona, Arizona Standards and Guidelines for the Effective Management of Adult Sex Offenders on Probation, (1999). <https://antipolygraph.org/documents/az-sex-offenders.pdf> Last accessed 18.08.2012.

52 D.R. Laws and C.L.Z. Gress 'Seeing Things Differently: The Viewing Time Alternative to Penile Plethysmography' (2004) 9 Legal and Criminological Psychology 183.

${ }^{53}$ A.R. Beech, et al. 'Risk Assessment of Sex Offenders' (2003) 34 Professional Psychology: Research and Practice 339.

${ }^{54}$ McGrath, op. cit. n. 33

${ }^{55}$ M. Foucault, Abnormal: Lectures at the Collège De France 1974-1975, (2003).

${ }^{56}$ Foucault, id. p. 55
} 
The most significant human monster for the medico-juridical powers was the paedophile and child murderer, exemplified in the cases of Henriette Cornier, Antoine Leger and Louis Auguste Papavoine. ${ }^{57}$ Indeed, it was paedophilia that constituted the unnatural or 'monstrous act' most potently. And so, as - over the course of the $19^{\text {th }}$ century, through the endeavours of scientists like Lombroso - there was a sort of democratisation of this concept, the monstrous act of paedophilia became entangled with the everyday of petty deviation. The monster, exceptional and rare at the start of this period, became "essentially an everyday monster, a monster that has become commonplace." 58 This democratisation was achieved through the coupling of the notion of monstrosity with the 'individual to be corrected' (ITBC). The ITBC was much more common than the monster, he was "typically regular in his irregularity," 59 a delinquent rather than a criminal, formed out of the tensions and interactions in families, neighbourhoods, schools, workshops and so on; but who is, in his or her irregularity, 'incorrigible'. Such incorrigibility, Foucault contends, created the need for "a new technology of rectification, of supercorrection," ${ }^{100}$ the traces of which we might find now in the penological and regulatory framework that invests increasing amounts of time and resource in organising the petty deviations from normality in families, education and so on, for example in the context of ADHD. ${ }^{61}$ Thus, notions of monstrosity and of everyday irregularity were wedded to a need to correct, improve and restore. ${ }^{62}$

Finally, the monster and the ITBC, each already carrying the marks of a 'grotesque sexuality', fused at both the conceptual level and at the level of response and management, with the masturbator, a newly discovered actor in the $19^{\text {th }}$ century, whose onanism called for supervision by the family, by doctors and psychiatrists, by schools and by other institutions. Such supervision was necessary because of the terrible consequences of masturbation, seen as "the possible root, even as the real root, of almost every possible evil," ${ }^{\prime 3}$ the "explanatory principle of pathological singularity." ${ }^{14}$ The reason for masturbation's centrality in this period had to do with the appearance of the sexual body of the child ${ }^{65}$. Explanations for adult abnormality were thus connected to observations of childhood sexuality and the failure of parents and other figures of authority to properly control the behaviour of the child. Foucault argues that these figures began to overlap as the techniques of power that constituted them came to form a more coherent technology of abnormality that merged juridicopolitical powers, medical practices, family and disciplinary techniques, and technologies of the individual body.

The product of the synthesis of these three types of deviant was the 'abnormal', a paradox that became embedded in the social fabric, the positing in human form of the possibility that monstrosity and raw dangerousness might lie behind every petty deviation. Thus the everyday became ever more risky and a need emerged to understand the development of criminal behaviour and the passage

\footnotetext{
57 M. Foucault, Essential Works of Foucault, 1954-1984, Volume 1: Ethics, Subjectivity and Truth (1997).

${ }^{58}$ Foucault, op. cit. n. 55 p. 57

${ }^{59}$ Foucault, id. p. 58

${ }^{60}$ Foucault, id. p. 59

${ }^{61}$ Crawford, op. cit. n. 45

62 Foucault, op. cit. n. 57

${ }^{63}$ Foucault, op. cit. n. 55 p. 59

${ }^{64}$ Foucault, id. p. 60

${ }^{65}$ Foucault, op. cit. n. 57
} 
into this unfathomable abnormal. It was psychiatry that most successfully claimed the right to speak on this subject and its particular skill was to identify the abnormal in the normal. We might think of it as having invented a house of mirrors in which the reflected image of the normal showed the peculiar distortions of this monstrous abnormality. Psychiatry claimed to be able to offer an explanation, to find abnormality "even where it is scarcely perceptible." 66 It did this through the abnormal's triadic structure and through development of mechanisms and concepts to look beyond the present and the presented, to the past, the antecedents and character, the bad habits and little irregularities that pushed out from normality into the abnormal. One of its most effective technologies for this work was the confession, borrowed from Christianity but transformed into a tool for the scientia sexualis. ${ }^{67}$ It used confession to look beyond visible symptoms, locating abnormality at the level of (the newly discovered) instincts, drives, and desires.

It is our contention that during the polygraph and plethysmograph examinations of the sex offender we find the application of this logic of abnormality. Following Foucault, we argue that the treatment apparatus around the offender seeks to produce knowledge about the subject's petty deviations and his monstrous acts in order to control the raw monstrosity that lies below them. However, the three faces of the abnormal are not equally represented in the portrait of every criminal and so, as Foucault argues, one might be the more dominant force in constituting a particular apparatus of control and knowledge. In the case of the paedophile it is the human monster that plays an important role since it facilitates a constitution of him as fundamentally dangerous and thus incurable. Importantly, this monstrous desire is connected to a discourse of risk-management, which we detail in the following section.

\section{Denial, Deception and the Incurably Risky Offender}

Lacombe $^{68}$ describes a particular history of psychiatric work that, though beginning with an aspiration towards a cure for sexual offending, ultimately lost optimism. Indeed, in the contemporary discourses surrounding the use of the polygraph for the management of sex offenders, the offender is viewed as an inherently dangerous and risky individual, for example in the following quote from the Arizona Guidelines ${ }^{69}$ on the containment approach: "Sexual offending is a behavioral disorder which can often be managed but not 'cured'."

Kim English, ${ }^{70}$ one of the major US proponents of the containment approach reports that "the polygraph [is] an essential component of community supervision of sex offenders." But if the device isn't facilitating the cure of these individuals, but remains an essential component of the supervision programme, what is the purpose of all this documenting of the offender's desires and deviations? The answer lies in the epistemological demands of the risk agenda. Though the sexual history

\footnotetext{
${ }^{66}$ Foucualt, id. p. 120

${ }^{67}$ M. Foucault, The Will to Knowledge: The History of Sexuality Vol 1, (1998).

${ }^{68}$ D. Lacombe 'Consumed with Sex: The Treatment of Sex Offenders in Risk Society' (2008) 48 British Journal of Criminology 55.

${ }^{69}$ Arizona, op. cit. n. 51

${ }^{70} \mathrm{~K}$. English 'The Containment Approach: An Aggressive Strategy for the Community Management of Adult Sex Offenders ' (1998) 4 Psychology, Public Policy and Law 218.
} 
disclosure examination is more common to the US system, the polygraph's contextualisation in the risk agenda is significant as regards its legitimisation in both the UK and USA. For instance, Grubin ${ }^{71}$ and Madsen, two UK scientists, state that the polygraph: "provides clinicians with more reliable sexual histories, more complete and accurate offence descriptions, and a greater likelihood of identifying high-risk behaviours, enabling intervention to take place before re-offending occurs."72 This notion of identifying high-risk behaviours and of intervention is characteristic of the contemporary approach to sexual offenders, as English notes, it is a "case management and risk control approach that is individualized based on each offender's characteristics." 73

The polygraph becomes effective because sex offenders, in the various guidelines, reports and scientific papers are characterised as being inherently deceptive. In Lacombe's $\mathrm{s}^{74}$ ethnography of a treatment programme for sex offenders she frequently encountered the notion that offenders are naturally deceptive or are in 'denial'. She provides useful snippets of dialogue from her observations, evidencing in one example how a treatment professional incessantly cajoles an offender into acknowledging that they are in denial. This is the key to the legitimation of polygraphy and plethysmography: that the sex offender is conceived of as secretive, as one who lies about their crimes. In this context the polygraph facilitates the production of confessions of deviance and desire. Indeed, it is hard to miss the centrality of its effect on the frequency of confessions made by offenders to the arguments supporting the technique's use. For example, in Grubin and Madsen:

"it should also be noted that in post-conviction testing the emphasis is ...on the facilitation of disclosures relevant to supervision and treatment." 75

Most clearly there is an acknowledgement by some that it needn't matter that the device may not be up to the usual scientific standards so long as it convinces offenders to account their sexual histories in increasing amounts of detail. So one finds, for instance, Ahlmeyer et al. agreeing with Chambers ${ }^{76}$ that:

"the polygraph is not a test, but a treatment tool designed to elicit a client's admissions to past behaviors and monitor current behaviors. Many therapeutic interventions that do not meet the standards requiring adequate documentation of practice standardization, reliability, and validity, are nonetheless effectively utilized in the field." ${ }^{\prime 7}$

As such, the way in which the polygraph is primarily understood to be assisting treatment

\footnotetext{
${ }^{71}$ Grubin has been significantly influential in bringing the polygraph from the USA to the UK and has been responsible for overseeing the UK trials.

${ }^{72}$ D. Grubin and L. Madsen 'Accuracy and Utility of Post-Conviction Polygraph Testing of Sex Offenders' (2006) 188 The British Journal of Psychiatry 479.

${ }^{73}$ K. English 'The Containment Approach to Managing Sex Offenders' (2004) 34 Seton Hall Law Review 1255.

${ }^{74}$ Lacombe, op. cit. n. 68

${ }^{75}$ Grubin and Madsen, op. cit. n. 72 p. 482

${ }^{76} \mathrm{H}$. Chambers 'Snohomish County Juvenile Court Sex Offender Treatment Program: Policy Statement on the Use of Polygraph in Treatment of Juvenile Sex Offenders' (1994) November Interchange 1.

${ }^{77} \mathrm{~S}$. Ahlmeyer, et al. 'The Impact of Polygraphy on Admissions of Victims and Offenses in Adult Sexual Offenders' (2000) 12 Sexual Abuse: A Journal of Research and Treatment 123., p. 125
} 
professionals is through its effect on the confessional behaviour of the offender whether or not it 'works'. As such, the long history of scientific contention surrounding the polygraph is neatly sidestepped in the sex offender literature. The significance of the elicitation of further confessions of victims, or sexual fantasies, of childhood acts of masturbation, etc., etc. is that more information is equated to better risk management, which is essential in the case of the sex offender because of his construction as incurable and monstrous, both in the treatment discourse, popular media and governance response.

So, whilst there is a continuance from the homosexual to the paedophile, since the policing of homosexual offences may have often posited the homosexual as predatory or corrupting, as the sex offender is now understood to be, there is also a discontinuity since the crucial aspect of homosexual offences was that they constituted a criminalisation of acts irrespective of the consent of the participants and that was because the act itself was immoral. In other words, it was a moral economy which underpinned the substantive offences and in which the polygraph found itself valuable. The underpinning logic of contemporary offences, paedophilic offences in particular, is no longer morality but risk ${ }^{78}$. In the context of the sex offender this means that monstrous acts are now understood through a risk-management agenda that does not seek to rectify this monstrosity, only to help control it.

Research in the diagnosis of sex offender risk now shuns as 'subjective' the professional, clinical opinion of individual risk, with some studies arguing that it is only marginally better than chance. ${ }^{79}$ This scepticism often goes hand-in-hand with the assertion that more formal, algorithmic procedures for risk assessment are at least as good, if not better than professional opinion. ${ }^{80}$ Indeed, it is increasingly a particular kind of actuarial risk that operates in their assessment and management, ${ }^{81}$ which represents an exceptionally clear example of the adoption of logics from insurance and capital systems into medical and legal spaces.

There are a number of formal risk-assessment 'technologies'82. One of the earlier techniques developed was Rapid Risk Assessment for Sex Offender Recidivism (RRASOR), developed by Karl Hanson. ${ }^{83}$ RRASOR produces a score from 0 to 5 , so as to screen offenders into relative risk levels.

\footnotetext{
78 M.M. Kleinhans 'Criminal Justice Approaches to Paedophilic Sex Offenders' (2002) 11 Social \& Legal Studies 233., McAlinden, op. cit. n. 48 (2006), O’Malley, op. cit. 47

${ }^{79}$ R.K. Hanson 'What Do We Know About Sex Offender Risk Assessment?' (1998) 4 Psychology, Public Policy, and Law 50, R.K. Hanson and M.T. Bussiere 'Predicting Relapse: A Meta-Analysis of Sexual Offender Recidivism Studies' (1998) 66 Journal of consulting and clinical psychology 348, R.K. Hanson and D. Thornton 'Improving Risk Assessments for Sex Offenders: A Comparison of Three Actuarial Scales' (2000) 24 Law and Human Behavior 119.

${ }^{80}$ See, for example: W.M. Grove and P.E. Meehl 'Comparative Efficiency of Informal (Subjective, Impressionistic) and Formal (Mechanical, Algorithmic) Prediction Procedures: The Clinical-Statistical Controversy' (1996) 2 Psychology, Public Policy, and Law 293.

${ }^{81}$ E.H. Meijer, et al. 'Sex Offender Management Using the Polygraph: A Critical Review' (2008) 31 International Journal of Law and Psychiatry 423.

${ }^{82}$ For an overview see Hanson and Thornton, op. cit. n. 79 (2000)

${ }^{83}$ R.K. Hanson, The Development of a Brief Actuarial Risk Scale for Sexual Offense Recidivism. User Report 9704, (1997).
} 
The scoring of offenders in this measure is based on such factors as the number of past sexual offense convictions he has or his age at assessment (e.g. if he is under 25 he is deemed more likely to re-offend). But it also involves information about the kind of relationship he has to his victims and the sex of his victims is also accounted since offences against male victims are viewed as an increased risk factor. Another tool, more commonly used in the UK, was developed by David Thornton for HM Prison Service and is known as Structured Anchored Clinical Judgement (or SACJ). It is a three step process taking into consideration a broader range of risk factors. Such things as whether the offender has ever been married, has a substance abuse problem, has been in care, scores $25+$ on the psychopathy checklist, and a range of other factors play a role in determining the sexual offender's risk of recidivism. ${ }^{84}$ In both systems points are accumulated for these factors and then used to assign the offender to varying levels of risk (e.g. levels I-III, in SACJ).

What these actuarial technologies have in common, and there are now numerous variations ${ }^{85}$ is an approach to the offender as assessable, objectively so, as regards his likelihood of re-offense. So he can be managed, since this is the primary concern of a treatment programme that has eschewed any claim to cure him for good. As Grubin comments:

"Sex offending is not a disease, and it does not lend itself to a cure... One can, however, lower the risk of such re-offending significantly in some individuals, and decrease the frequency of offending in others." 86

Or in the Colorado Sex Offender Management Board guiding principles:

Many offenders can learn through treatment to manage their sexual offending behaviors and decrease their risk of re-offense. Such behavioral management should not, however, be considered a "cure," and successful treatment cannot permanently eliminate the risk that sex offenders may repeat their offenses. ${ }^{87}$

In this context, the algorithmic approaches to sexual offender risk management create a need for more information since more information is understood to produce more accurate risk assessment. In the UK context, for example, the preliminary MOJ report in 2010 and the final report in 2012 offered favourable evaluations of the UK trials of polygraphy with sex offenders, both focussing on the increased number of 'clinically significant disclosures' (CSDs) made by offenders on probationary programmes adopting the polygraph as compared to those on programmes without the device. This emphasis on the number of CSDs is understood through a discourse of risk-management, which will prove central to our analysis of the emergence and function of the device in later sections. Take the following statement from the 2012 report on the UK trials of the polygraph:

\footnotetext{
${ }^{84}$ D. Grubin, Sex Offending against Children: Understanding the Risk, Police Research Series Paper 99, (1998). $<$ http://library.npia.police.uk/docs/hopolicers/fprs99.pdf> Last accessed 18.08.2012.

${ }^{85} \mathrm{So}$, for instance, the RRASOR and SACJ were combined into the Static-99 risk assessment tool, or there is the more contemporary technique, Risk Matrix 2000.

${ }^{86}$ D. Grubin, Sex Offending against Children: Understanding the Risk, Police Research Series Paper 99, (1998). $<$ http://library.npia.police.uk/docs/hopolicers/fprs99.pdf> Last accessed 18.08.2012., p. 42

${ }^{87}$ C.S.O.M.B, Standards and Guidelines for the Assessment, Evaluation, Treatment and Behavioral Monitoring of Adult Sex Offenders, (2011). <http://dcj.state.co.us/odvsom/sex_offender/documents.html> last accessed 18.08.2012.
} 
"Polygraph testing has increased the chances that a sexual offender under supervision in the community will reveal information relevant to their management, supervision, treatment, or risk assessment. It has also increased the likelihood of preventative actions being taken by offender managers to protect the public from harm." ${ }^{88}$

However, to get information on such factors the offender has to produce disclosures, and this is something that the treatment literature opines offenders are emphatically averse to doing, for example:

"Any assessment of a sex offender should include ...information about the antecedents, the
behaviors, and the consequences of offending (the $A B C$ model). This should include the
actual behaviors carried out, along with the accompanying thoughts and emotions.
Unfortunately, this is not always a straightforward task with sex offenders because they are
frequently in some degree of denial about aspects of the offense and are therefore not
willing to be completely truthful about the information that the assessor needs to obtain." 89

It is this mysterious space of emotions and thoughts that the actuarial risk assessment technologies cannot access because the offender is constructed as being deceptive. The polygraph and the plethysmograph, therefore, make excellent conceptual additions to the apparatus surrounding the offender because they are understood to offer access to this affective terrain, and, as the studies continue to show, they produce greater numbers of confessions about deviant desire and abnormal behaviour. As such, the polygraph and plethysmograph function to sustain an algorithmic system of risk assessment by facilitating the overcoming of denial and the exposure of deception. That the technologies might not actually work, that they might just be one more instance of the bogus pipeline ${ }^{90}$ isn't too much of a worry so long as more admissions are made and risk can be managed.

\section{Performing Deviant Sexuality}

Perhaps, though, there is something more occurring when sex offenders are made subject to these management technologies. Certainly there is the risk-management logic, but the offender's denial of their crimes and their consistent deception, or at least their characterisation as such by treatment providers, poses an additional problem. Not acknowledging their crimes as planned, claiming that they didn't intend to rape or molest, suggesting it was a spontaneous act clouded by drunkenness or drug use, all these things make sex offenders even more dangerous than their actions, even more

\footnotetext{
${ }^{88}$ T.A. Gannon, et al., The Evaluation of the Mandatory Polygraph Pilot, (2012). Ministry of Justice Report, ISBN: 978-1-84099-555-8.

${ }^{89}$ Beech, et. al., op cit. n. 53 p. 340

${ }^{90}$ The term for creation of a 'fake lie detector' for use in ensuring truthful responses in psychological studies, which has, for instance been used to produce more 'honest' responses from women during psychological inquiry into their sexual lives in: M.G. Alexander and T.D. Fisher 'Truth and Consequences: Using the Bogus Pipeline to Examine Sex Differences in Self-Reported Sexuality' (2003) 40 Journal of Sex Research 27. It has also been adopted in one study to increase honesty in paedophiles by use of what essentially amounted to a fake polygraph machine, see: T.A. Gannon, et al. 'Increasing Honest Responding on Cognitive Distortions in Child Molesters: The Bogus Pipeline Revisited' (2007) 19 Sexual Abuse: A Journal of Research and Treatment 5.
} 
violent than their crimes. By resisting their exclusion as fundamentally different they place all sexual activity at risk of becoming abnormal because, following Foucault's analysis, the construction of the 'abnormal' as a category involved the process of democratisation of monstrosity into the everyday, petty deviations from normality.

Part of this risk of abnormality being found in everyday, 'normal' sexuality is because, as Kleinhans argues, "Intense public reactions to paedophiles derive directly from contemporary conceptions of delineations between childhood and adulthood." ${ }^{91}$ No longer obsessed with onanism, the contemporary account of childhood sexuality is on the child as asexual. This construction is put at risk by paedophiles and in particular by those who refuse to acknowledge that their actions constitute a crime, or that the child also desired the sexual relationship. In order to protect these binaries of innocence/adulthood, paedophile/normal not only do we have to produce information about the paedophile as risky, we must also constitute them as fundamentally different to us. But this leaves them too close to the terrifying spectre of human monstrosity. This total othering would leave them as an uncontrollable risk, so post-probation strategies have to engage offenders in a practice of self-management that teaches them to re-direct their deviance towards normality.

As Lacombe describes the situation in the USA, from around the 1980s, which is also when polygraphy began to properly integrate with sex offender management programmes, the treatment of paedophiles began to include cognitive management strategies and social skills modules. ${ }^{92}$ The purpose of these treatment programmes became to teach offenders to behave normally. So, for instance, of a number of currently used 'behavioural sexual arousal control techniques' in the US, the practices of 'covert sensitization' and 'minimal arousal conditioning' ${ }^{93}$ have been adopted in more than half of the US programmes. ${ }^{94}$ These techniques access the ways in which the offender directs his desire and trains him to interrupt existing chains of fantasy and behaviour. Through addition of other practices such as 'orgasmic conditioning' or 'masturbatory satiation' the offender is encouraged to direct his desire towards more appropriate objects. These technologies of desire are quite revealing of an underlying heteronormative or even homophobic tone in offender treatment that often embeds particular ideals about age-appropriate (i.e. middle-aged partners for middleaged men), female-male relationships..$^{95}$

Moreover, around a quarter of US training programmes include 'aversive behavioural rehearsal' ${ }^{96}$ As part of this particular practice the offenders must create detailed descriptions of their abuse of victims, write a narrative of the event from their victim's perspective and then act out, through roleplay, the victimization. First, offenders role-play as their victim with another group member playing out their abuse patterns on them, and then they switch roles and the offender plays himself as another group member plays his victim. During these role-plays the offender is encouraged to

\footnotetext{
${ }^{91}$ Kleinhans, op. cit. 78. p. 234

92 Lacombe, op. cit. n. 68 p. 57

93 B.M. Maletzky, Treating the Sexual Offender, (1991).

${ }^{94}$ McGrath, op. cit. n. 33

${ }^{95}$ Lacombe, op. cit. n. 68

${ }^{96}$ S.D. Webster, et al. 'Developing Empathy in Sexual Offenders: The Value of Offence Re-Enactments' (2005)

17 Sexual Abuse: A Journal of Research and Treatment 63.
} 
narrate in the first-person, present tense, describing the thoughts, feelings and fantasies he experienced during the assault. ${ }^{97}$

The procedure thus requires the offender to re-perform the detailed events of the crimes for which he has been convicted, which he might deny are sexually abusive or perhaps denies were planned, or perhaps denies altogether, in front of a group of other offenders and treatment professionals so that he can no longer deny his guilt. Such practices have, on occasion, raised concerns in the literature and Pithers, for example, outlines a very serious case in which offenders were forced to perform role-plays of abuse that they themselves had suffered as children, some realistically using details provided to therapists ${ }^{98}$. Clearly it is not the overt intention of therapists to abuse their clients but these behavioural technologies are not only questionable they are evidently damaging and perhaps represent an eruption, within the discourse and practice of treatment, of a desire to further punish the offenders.

The insistence that the offender produce more detailed information about his crimes, and the use of the polygraph and the plethysmograph to elicit even greater numbers of disclosures are all modes of encouraging the offender's confession of guilt and abnormality. Foucault's well-known work on confession $^{99}$ certainly helps in regard to understanding the emergence of the subject as one increasingly expected to confess his sexual desires. Indeed, confession has, for a long time now, been the norm of psychiatric couch-therapy and group sessions. Foucault has provided a detailed account of how the confession of all of one's sins for penance in Christian practice became the model for psychological examination and treatment of the subject's abnormality ${ }^{100}$. However, it is important to note that confession is not an abstract process and that it occurs instead in specific 'scenes' or contexts that colour the value of the disclosures. Confession is thus a function of its mode of address, the substantive questions asked and answers demanded and is, in this respect, performative of an identity. ${ }^{101}$

The performative nature of confession, so that confession is not seen to produce the truth but only a particular and warranted truth, constrained, mandated but also made possible by the discourse in which it is performed, is understood by Butler as a move which both undermines the idea that confession accesses the pure presence of the unmediated, original and authentic self, and emphasises the agency of the confessing person - his or her choice over what to confess and how to perform that act of confession. ${ }^{102}$ However, this mixing of choice and constraint simply does not apply to the performative space of the containment approach as regards the polygraph, the plethysmograph and these practices of re-enactment of abuse and re-direction of desire. Required to role-play the crimes for which he was convicted is a mode of performance over which the offender has limited control. The choice in confession is even more removed from the animated intention of the individual when seemingly located in the body of the offender by the polygraph or

\footnotetext{
${ }^{97}$ W.D. Pithers 'Process Evaluation of a Group Therapy Component Designed to Enhance Sex Offenders' Empathy for Sexual Abuse Survivors' (1994) 32 Behaviour Research and Therapy 565, W.D. Pithers 'Maintaining Treatment Integrity with Sexual Abusers' (1997) 24 Criminal Justice and Behavior 34., Webster, id. 98 Pithers, id. (1997)

${ }^{99}$ Foucault, op. cit. n. 67

${ }^{100}$ Foucault, id., Foucault, op. cit. n. 55

101 J. Butler, Giving an Account of Oneself, (2005).

102 Butler, id.
} 
plethysmograph. In this way, the scenes of his various confessions serve in part to delegitimise any claim to innocence, not through accessing and objectively revealing the singular truth of his crimes, as might ostensibly be the case, but through the actual enactment of an abnormal sexual event during treatment, whether as a performance in role-play or as his erection during plethysmography, or of a deceptive arousal during the polygraph exam. Thus these confessional apparatuses are performative in that they serve to enact a deviant, criminal desire and thus function to constitute the offender as a paedophile there and then thereby avoiding his deception or denial of his crimes and making him more amenable to risk management strategies.

\section{The Paradox of Ab/normal Sexuality}

An important consequence of the use of the polygraph and plethysmograph is that it constitutes the sex offenders abnormality as bodily and as fundamental. This fits well with Foucault's identification of the various components that came to overlap in the construction of the abnormal and in his work on confession. In the abnormal, the human monster was incurably other since they violated all laws both natural and legal, epitomised by the sexual monster or paedophile. This meant that they were fundamentally outside of law, and thus constituted the 'other' of sexual normality in its most unfathomable and dangerous form. This logic of fundamental monstrosity was connected up with the body in other forms of human monster, such as those who had physical deformities, but also through the myriad practices organised around the ITBC. This constituted the abnormal as a paradox, since it linked observations of everyday social and physical deviation to the fundamental monstrosity of paedophilia and child murder. The same practices for identifying these clues to monstrosity were used to examine truth of normal sexuality, which in confessional logic, meant that the body and its desires came to be the deepest truth of human subjectivity. In much the same way, sexual desires and bodily truth in the context of the containment approach cannot be fundamentally altered, only modified through routinized internalisation of practices for the performance of normal behaviour.

Contrary to this binary bodily determination of sexual desire and practice, a number of scholars have argued that the traditional binaries of sexual desire through which to interpret the truth of sexual subjectivity are becoming more plastic ${ }^{103}$ and liquid ${ }^{104}$. Some see this as a liberating force in which novel intimacies might be developed, others as the source of postmodern anxieties that lead to violence. Perhaps the construction of a foundation for abnormal desires that cannot be cured is also structured around the preservation of a fundamental normality. This pursuit of incurable desires, normal and abnormal, perhaps serves as one force in the laying of foundations to protect against the stormy waters of liquidity in constituting late capital identities. ${ }^{105}$

However, constituting the offender as unable to control his desires because they are incurable doesn't only lead to problems of permanent management but also to notions of guilt. For the offender to be responsible for their crimes they have to have chosen to commit them; the offender cannot be seen as a victim of his own monstrosity. Furthermore, in order to protect the community the offender has to remain manageable in some form. For risk-management strategies to be effective they must conceptualise the offender as being able to, through training, control his

\footnotetext{
${ }^{103}$ A. Giddens, The Transformation of Intimacy: Sexuality, Love and Eroticism in Modern Societies, (1993).

${ }^{104}$ Z. Bauman, Liquid Love: On the Frailty of Human Bonds, (2003).

${ }^{105}$ Z. Bauman and B. Vecchi, Identity: Conversations with Benedetto Vecchi, (2004).
} 
riskiness. In this respect he can remain responsible, which is to say offenders are constituted not with a choice in desire but with a choice in actions. And so it is at the level of performance that the offender is offered choice and thus responsibility. Polygraphy, plethysmography and other practices thus become technologies that help constitute the offender: they are technologies of channelling and managing desire at the level of performance organised alongside various strategies of disciplinary power. But, the idea that the offender might be able to permanently manage his identity as performance and thus appear as normal unsettles the easy categorisation of ab/normal on the basis of behaviour. It makes all performances of sexuality risky and exposes the paradox of abnormality.

This is a paradox that contributes to a society of suspicious love, the eroticisation of family relations, or a 'funny world' 106 in which innocence and goodness become difficult to distinguish from guilt and sin. This, perhaps, explains the targeting of the paedophile in the 'new penology' and why much of the surveillant assemblage placed around the offender, from Megan's Law-style name-and-shame practices to the polygraph and plethysmograph have the effect of branding him, 'outing' him, making him visible and thus 'containing' him whilst allowing him back in to the community. As Bauman argues in the rather different context of political collapse:

[They] are not feared and hated for being different - but for being not different enough, mixing too easily into the crowd. Violence is needed to make them spectacularly, unmistakably, blatantly different. Then by destroying them one could hopefully eliminate the polluting agent that blurred the distinctions and thereby recreate an orderly world in which everyone knows who they are and identities are no longer frail, uncertain and precarious. ${ }^{107}$

In US sex offender management discourse and increasingly in the UK, the sex offender has become the far pole of human monstrosity, the cold outside of a taxonomy of norms and abnorms, of gross abuses and petty deviations. He is the limit of a certain set of relations of permissions and denials, of fantasies and realities, in which we are all implicated. The practices of sex offender management perhaps seek to destroy this pollution of the normal that occurs through the offender's deception and denial, through their refusal to be cemented as deviant. In the context of risk management, it is this anxiety of the paradox of abnormality that underlies the management of sex offenders in the containment approach, which is thus not rehabilitative but performative. It consolidates the offender's fractious behaviours, denials, deceptions, crimes and fantasies into a singular abnormal identity in which he remains dangerous but can be managed, contained but never cured.

\footnotetext{
106 "Even love is under suspicion these days isn't it? It's a funny world when a father can't love his own daughter." Dialogue from Bill Naughton's The Family Way, Roy Boulting (director), 1966.

${ }^{107}$ Bauman, op. cit. n. 105, p. 58
} 